\title{
Nuwe dinge in Nuwe woorde* — 'n oorsig oor buitemikrostrukturele leksikografiese vernuwings
}

\author{
Herman L. Beyer, Departement Germaanse en Romaanse Tale, \\ Universiteit van Namibië, Windhoek, Namibië
}

\begin{abstract}
New Things in New Words* - an overview of nonmicrostructural lexicographic innovations. This review article focuses on the nonmicrostructural lexicographic innovations which are apparent in the dictionary under discussion. The emerging notion of user-friendliness in modern lexicographic practice does in no way imply that lexicographic innovations should be limited to the microstructure of dictionaries. Innovative approaches to the presentation of information in the user's guide (where a user's guide exists in a dictionary!) and other elements of the front and back matter in dictionaries play as an important role in making a dictionary more user-friendly as do innovations in the microstructure. New Words/Nuwe woorde, as the newest contribution to the collection of Afrikaans translation dictionaries, exhibits some remarkable nonmicrostructural lexicographic innovations. These innovations are highlighted, evaluated and criticised in this article.
\end{abstract}

Keywords: ACCESSIBILITY, BACK MATTER, DICTIONARY USER, FRONT MATTER, INFORMATION TYPES, LEXICOGRAPHER, LEXICOGRAPHIC INNOVATIONS, LEXICOGRAPHY, MACROSTRUCTURE, MEDIOSTRUCTURE, MICROSTRUCTURE, NONMICROSTRUCTURAL LEXICOGRAPHIC ELEMENTS, PRONUNCIATION GUIDANCE, TRANSLATION DICTIONARY, USER'S GUIDE, USER-FRIENDLINESS

Opsomming: Hierdie resensieartikel fokus op die niemikrostrukturele leksikografiese vernuwings wat in die woordeboek onder bespreking voorkom. Die toenemende bewustheid van gebruikersvriendelikheid in die hedendaagse leksikografiese praktyk beteken nié dat leksikografiese vernuwings tot die mikrostruktuur van woordeboeke beperk moet word nie. Vernuwende benaderings tot inligtingsaanbod in die gebruikerstoeligting (as daar een in die woordeboek is!) en ander elemente in die voor- en agterwerk van woordeboeke speel 'n ewe belangrike rol in die gebruikersvriendelik maak van woordeboeke as vernuwings op mikrostrukturele vlak. New Words/Nuwe woorde, as die nuutste toevoeging tot die versameling Afrikaanse vertalende woordeboeke, vertoon 'n aantal besondere buite-mikrostrukturele leksikografiese vernuwings. Hierdie vernuwings word in hierdie artikel uitgelig en geëvalueer.

Sleutelwoorde: AGTERWERK, BUITEMIKROSTRUKTURELE LEKSIKOGRAFIESE ELEMENTE, GEBRUIKERSLEIDING, GEBRUIKERSVRIENDELIKHEID, INLIGTINGSTIPES, LEKSI-

* Du Plessis, Madaleine (Hoofred.). 1999. New Words, and previously overlooked ones/Nuwe woorde, en oues wat in die slag gebly het. Kaapstad: Pharos.

Lexikos 10 (AFRILEX-reeks/series 10: 2000): 275-290 
KOGRAAF, LEKSIKOGRAFIE, LEKSIKOGRAFIESE VERNUWINGS, MAKROSTRUKTUUR, MEDIOSTRUKTUUR, MIKROSTRUKTUUR, TOEGANKLIKHEID, UITSPRAAKLEIDING, VERTALENDE WOORDEBOEK, VOORWERK, WOORDEBOEKGEBRUIKER

\section{Inleiding}

In ' $\mathrm{n}$ tyd dat Afrikaans onder verskillende tipes druk verkeer, is die verskyning van die woordeboek New Words/Nuwe woorde 'n baie tydige teken dat die taal lewenskragtig funksioneer en heeltemal in staat is om aan die eksponensieel toenemende taaleise van die inligtingsontploffing te voldoen. Hierdie siening word ondersteun deur 'n opmerking in die Voorwoord:

Dis 'n publikasie wat gegrond is op taal soos dit in die praktyk gebruik word. Die redaksie het sy werk deurlopend getoets aan die omvangryke databanke wat Pharos tot sy beskikking het. Slegs by hoë uitsondering, wanneer bronsoektogte doodgeloop het, is vertaalekwivalente agter lessenaars geskep.

Vanuit ' $n$ metaleksikografiese oogpunt is dit ook verblydend om op te merk dat hierdie publikasie 'n aantal leksikografiese vernuwings bevat, wat tekenend is van die redaksie se kennisname van onlangse ontwikkelinge in die metaleksikografie. Dit is op hierdie vernuwings waarin hoofsaaklik in hierdie resensieartikel kommentaar gelewer word, en die bespreking sal fokus op die buitemikrostrukturele elemente waarin leksikografiese vernuwings voorkom. Uitspraakleiding as mikrostrukturele element verdien egter besondere vermelding en word daarom by die bespreking ingesluit.

In die Voorwoord word gemeld dat hierdie woordeboek saamgestel is om Pharos se bestaande tweetalige handwoordeboeke aan te vul. Hiervan is die veertiende, uitgebreide uitgawe van Groot woordeboek/Major Dictionary (Eksteen 1997) (voortaan GW) en die eerste nuwe uitgawe van Tweetalige Frasewoordeboek/Bilingual Phrase Dictionary (Joubert 1997) (voortaan TFW) die nuutste. Veral eersgenoemde sal vergelykenderwys in die bespreking van enkele van die belangrikste buitemikrostrukturele leksikografiese vernuwings in New Words/Nuwe woorde (voortaan NW) betrek word.

Die teikengebruikers van NW is waarskynlik die gemiddelde gebruikers van GW en TFW, en meer bepaald waarskynlik taalpraktisyns in alle professies.

\section{Gebruikersgerigtheid}

'n Belangrike kriterium in die evaluering en saamstel van woordeboeke is die konsep van gebruikersvriendelikheid of gebruikersgerigtheid. Kromann, Riiber en Rosbach (1991: 2713) noem hierdie kriterium "the user aspect, which 
involves consideration on the part of the lexicographer for the dictionary's target group, its needs and competence, and the types of user situations that occur." Omdat die woordeboek as die belangrikste houer van taalkundige inligting vir die gewone taalgebruiker beskou word (vgl. Gouws 1989: 1), behoort dié inligting op 'n toeganklike wyse vir die gemiddelde woordeboekgebruiker aangebied te word. Volgens Louw en Gouws (1996: 92) is gebruikersgerigtheid en woordeboektoeganklikheid van die eise wat toenemend aan leksikograwe gestel word.

Lombard (1994) gebruik die metafoor van 'n driehoek om die verhouding tussen die drie belangrikste rolspelers ten opsigte van woordeboeke (d.i. die leksikograaf, die taalkundige en die woordeboekgebruiker) uit te beeld. In terme van hierdie verhouding verwag die taalkundige onder meer 'n akkurate aanbod van taalkundige inligting, terwyl oor die gebruikersaspek beweer word dat "lexicographers can be and often are guilty of creating ... tension [in this triangle - HLB], inter alia by including features in the dictionary which are pleasing to them but baffling to their users" (Lombard 1994: 205). Hierdie verskynsel kan vermy word deur meer aandag aan gebruikersvriendelikheid in die saamstel van 'n woordeboek te skenk. Hausmann (1989: 13, in Gouws 1999:

7) karakteriseer gebruikersvriendelikheid in woordeboeke dan ook tereg as die aanpassing van die leksikografie by die maatskappy. Vergelyk ook Van der Merwe-Fouché (1999) in hierdie verband.

Die gebruikersaspek geld dan ook as 'n belangrike maatstaf in die evaluering van die buite-mikrostrukturele vernuwings in NW.

\section{Die niealfabetiese gedeelte van die woordeboek}

Wiegand (1996: 135) beskou woordeboeke as draers van tekstipes of tekste. Met betrekking tot ander teksdraers, soos koerante en tydskrifte, word die ordening en struktuur van die tekste daarin deur historiese en pragmatiese praktyk bepaal. Daar bestaan dus geen onderlinge verband tussen die onderskeie tekste nie. Die verskillende tekste wat egter in 'n woordeboek verskyn (soos die voorwoord, die toeligting, die sentrale woordelys, die woordeboekartikels, e.s.m.) is nie slegs op ' $n$ bepaalde manier georden nie, maar is ook funksioneel in terme van inhoud, en struktureel in terme van vorm aan mekaar verwant, betoog Wiegand. Hierdie kombinasie van tekste noem hy 'n makroteks, en die beginsels waarvolgens die makroteks gestruktureer is, moet in 'n metateks verduidelik word. Die term metateks verwys na die gebruikersgids of toeligting (Wiegand 1996: 136).

Binne Wiegand (1996:136) se teksbenadering kan die tekste in 'n woordeboek aan een van drie tipes behoort: die verpligte voorwerk (waaronder die metateks), die verpligte sentrale woordelys (die makro- en mikrostruktuur) en 'n opsionele agterwerk. Die verband tussen die verskillende tekste word deur 'n min of meer gedifferensieerde woordeboekinterne mediostruktuur bewerkstellig (Wiegand 1996: 135). 
Binne hierdie raamwerk en binne die bestek van hierdie artikel (met gebruikersgerigtheid as belangrike kriterium) word leksikografiese vernuwings ten opsigte van die voorwerk en agterwerk van NW vervolgens bespreek, gevolg deur ' $n$ beskouing van vernuwings ten opsigte van die mediostruktuur.

NW se voorwerk bestaan uit 'n Voorwoord, 'n "Key to entries" en 'n lys redaksionele afkortings.

\subsection{Die "Key to entries"}

Teen die agtergrond van die toenemende bewuswording van die belangrikheid van gebruikersvriendelike gebruiksleiding is die uitvoerige "Key to entries" wat betref vertalende woordeboeke in Suid-Afrika 'n beduidende leksikografiese vernuwing. Hierdie verskynsel is ' $n$ verbetering op die tradisionele gebruiksleiding in GW, wat bloot uit die aangawe van 'n lys redaksionele afkortings en redaksionele simbole bestaan, en in TFW, wat soortgelyke inligting verskaf, hoewel dit in 'n skematiese formaat aangebied word.

Die toeligting onder die opskrif "Key to entries" word in die vorm van 'n skema bestaande uit voorbeeldartikels aangebied, waarin elkeen van die elemente waaruit artikels in die woordeboek sou kon bestaan, deur middel van tipografiese skadumerkers uitgelig en aan die hand van byskrifte verklaar word. Die lemma ("headword"), aard van homonimiese en polisemiese inskrywings, uitspraakleiding, meervoudsvorme, tempus, etiketaanwending en redaksionele simbole is ingesluit by die verskynsels wat, presies soos hulle in die mikrostruktuur verskyn, as voorbeeldmateriaal aangebied word. Dit maak die opneem van 'n aparte lys redaksionele simbole onnodig en lei die gebruiker meer effektief tot suksesvolle inligtingsontsluiting wanneer hy/sy die alfabetiese gedeelte van die woordeboek raadpleeg. Die verklaring van spesifieke inligtingstipes is ook makliker in dié formaat te vind as die gebruiker vanaf die mikrostruktuur terugverwys na die gebruiksleiding om duidelikheid oor 'n bepaalde inskrywing te kry.

Die hoop word uitgespreek dat hierdie gebruikersvriendelike aanslag, wat 'n groot verbetering op die uiters gebrekkige gebruiksleiding in GW is, dié verskynsel in al Pharos se toekomstige woordeboeke inlui.

Daar kom wel enkele geringe probleme en inkonsekwenthede in die "Key to entries" in NW voor, wat vervolgens kortliks uitgelig en bespreek word.

In die eerste plek is dit nie duidelik waarom die redaksie besluit het op 'n Engelse aanbod van die byskrifte tot die skema nie, veral gesien in die lig daarvan dat die waarskynlikste gebruiker een is wat vanaf Engels na Afrikaans vertaal, en as sodanig gewoonlik eerder Afrikaanstalig as Engelstalig is. Dié verskynsel is des te meer opvallend as die Voorwoord en lys van redaksionele afkortings, wat beide slegs in Afrikaans verskyn, vergelykend betrek word. Dit is te bevraagteken of hierdie gemengde taalaanbod in die voorwerk 'n gunstige indruk van reëlmatigheid by die gebruiker sal skep. 
Kritiek sou ook teen die uitsluitlike gebruik van streng taalkundige terme in die "Key to entries" ingebring kon word. Hoewel die redaksie die waarskynlik tegnieser term lemma ten gunste van die meer algemene headword vermy het, kom suiwer taalkundige terme soos homonym en collocator sonder enige verduidelikings in andersins eenvoudig geformuleerde verklarings voor. Dit is duidelik dat die redaksie die rol van die woordeboek as houer van taalkundige inligting, wat akkuraat in taalkundige terme beskryf kan word, erken en toepas. Hoewel aanvaar sou kon word dat die waarskynlikste gebruiker van die woordeboek die taalpraktisyn is wat hierdie terme sonder moeite verstaan, loop sodanige inligtingsaanbod egter wel die risiko om die gemiddelde gebruiker wat reeds gebruikersgidssku is, te vervreem. Een manier waarop hierdie risiko vermy sou kon word, sou wees om verduidelikende parafrases tussen hakies ná sodanige terme in te voeg. Dit sou meebring dat 'n byskrif tot die skema wat tans

Homonyms are marked with superscript numbers

lui (p.(x)), gewysig sou word tot

Homonyms (words with identical form but unrelated meanings) are marked with superscript numbers.

Op dié wyse word sowel die taalkundig geskoolde as taalkundig ongeskoolde gebruiker in hierdie belangrike gedeelte van die woordeboek geakkommodeer, en funksioneer die parafrase boonop as indirekte taalkundige skolingsgeleentheid ten opsigte van die taalkundig ongeskoolde gebruiker.

Die tipografiese merkers wat aangewend word om doeltaalsinonieme en doeltaalsinoniemparadigmas van mekaar te onderskei, word deur middel van die volgende gesamentlike byskrif by een voorbeeldartikel verklaar:

Target-language synonyms are separated by commas. Translations with distinctly separate meanings are separated by semicolons.

Dit is duidelik dat die redaksie hier wel die gebruik van die meer tegniese lekseem polyseme vermy het, wat die inligtingsaanbod meer gebruikersvriendelik maak.

Daar sou egter geargumenteer kon word dat die twee middele wat gebruik word eerder in twee afsonderlike voorbeeldartikels elk met sy eie byskrif verklaar word. Dit sou byvoorbeeld maklik kon gebeur dat die gemiddelde woordeboekgebruiker slegs die eerste drie kommas wat in die voorbeeldartikel uitgelig word as sodanig raaklees, en aanvaar dat die vierde uitgeligte leesteken ook 'n komma is. Verder sou dit ook kon gebeur dat die gebruiker slegs die eerste sin van die verduidelikende byskrif vlugtig lees, en nie die volledige inligting van die tweeslagtige byskrif inneem nie. Hierdie argument 
verkry verdere geldigheid daardeur dat al die ander voorbeeldartikels telkens vir die verduideliking van slegs een tipografiese verskynsel in die mikrostruktuur aangewend word. Dit sou ook meer funksioneel wees om tipografiese verskynsels wat gewoonlik in die mikrostruktuur naby mekaar voorkom, juis apart in die gebruikersgids te verduidelik, aangesien elkeen van dié verskynsels 'n eiesoortige funksie met eiesoortige implikasies vir die gebruiker veronderstel.

Indien die inligting oor die onderskeid tussen doeltaalsinonieme en doeltaalsinoniemparadigmas dan apart aangebied word, maar saamgegroepeer is in die gebruikersgids, sou dit ook doelmatig kon wees om die inligting oor hoe homonieme van mekaar onderskei word hiermee saam te groepeer, sodat alle eksplisiete inligting op grond van betekenis- en ekwivalentdiskriminasie as 'n eenheid aan die gebruiker gebied word. Tans is die inligting oor die onderskeid tussen homonieme die tweede inligtingstipe wat in die gebruikersgids aangetoon word, terwyl die inligting oor die aanduiding van sinonieme en poliseme sewentiende (tweede laaste) geplaas is. 'n Meer konseptuele organisasie wat betref die aanbod van inligting oor artikelstruktuur sou dus aanbeveel kon word.

Ten minste een tipografiese teken wat in die mikrostruktuur van die woordeboek verskyn, is nie in die "Key to entries" opgeneem nie, naamlik die gelykheidsteken (=). Dié teken kom onder meer in die volgende artikels voor:

(1) $\underline{\text { ad}} \cdot \min n .,($ infml. afk. $)=$ administration.

(2) $\underline{\underline{X}} \cdot$ mas $n .,($ infml. $)=$ Christmas.

(3) li cense $n .: \sim$ plate $(A m$. $)=$ numberplate.

Die hantering van die lemmas hierbo suggereer ' $n$ tipe kruisverwysing. Wat hier van belang is, is dat 'n redaksionele simbool aangewend word sonder dat dié simbool se betekenis in die gebruikersleiding verklaar word. Dit is nie duidelik of die simbool se gebruik enige makrostrukturele, mikrostrukturele of mediostrukturele implikasies vir die gebruiker (en die leksikograaf!) inhou nie. Boonop is dit nie 'n simbool wat gewoonlik in tweetalige woordeboeke soos GW verskyn nie. Hierdie verskynsel sal verder by die bespreking van die mediostruktuur aandag geniet (vgl. 4.2).

'n Volgende probleem by die "Key to entries" is die voorbeelde wat ten opsigte van 'n "idiomatic phrase" en ' $n$ "usage example" onderskeidelik aangebied word. Uit die aangawe van dié voorbeelde kan die gebruiker nie aflei wat die verskil tussen die aanbod van 'n idiomatiese uitdrukking en dié van 'n gebruiksvoorbeeld is nie, aangesien die twee mikrostrukturele aangawes op dié vlak tipografies identies is. Vergelyk (4) as die gebruiksvoorbeeldaangawe en (5) as die aangawe oor idiomatiese uitdrukkings:

(4) mov'ie $n$.: go to the $\sim s$ gaan fliek.

(5) wobbbly $n .:$ throw $a \sim$, (Br. infml.) die piep kry, die (aap/bobbejaan)stuipe kry, ontplof. 
Die enigste aanduiding vir die gebruiker dat die lemma in (5) in 'n idiomatiese uitdrukking voorkom, is die feit dat die Afrikaanse ekwivalent in die vorm van 'n idiomatiese uitdrukking aangebied word. Die idiomatiese uitdrukking word op geen ander manier (soos d.m.v. 'n rubriekopskrif) van die gewone gebruiksvoorbeeld in (4) onderskei nie. Die toeligting bevat dus geen inligting oor hoe idiomatiese uitdrukkings op watter manier ook al spesiale leksikografiese bewerking ondergaan nie, of dat brontaaluitdrukkings van doeltaaluitdrukkings (in plaas van bv. doeltaalparafrases) as vertaalekwivalente voorsien word nie. Dit is onvoldoende gebruiksleiding.

Mikrostrukturele konvensies wat goed in die "Key to entries" verantwoord word, is die gebruik van die skuinsstreep en van hakies. Met betrekking tot die skuinsstreep word die volgende artikel as voorbeeld in die gebruikersgids aangewend:

(6) a'lit.er-ate $n$. trae/onwillige leser

Daarnaas verskyn die volgende byskrif:

(7) Strokes separate alternative words: trae leser or onwillige leser.

Met betrekking tot die mikrostrukturele optrede van hakies word die volgende artikel as voorbeeld in die gebruikersgids aangewend:

ho, ho(, ho) tw., (nabootsing v. laggeluid) hô, hô(, hô).

Die finale inskrywing in dié artikel $((, h \hat{o}))$ is tipografies gemarkeer en dien as voorbeeld by die daaropvolgende byskrif:

(9) Letters or words in brackets are optional: hô, hô or hô, hô, hô.

Die duidelike uitspel van die konvensies in (7) en (9) het tot gevolg dat die gebruiker maklik die inligting in 'n artikel soos dié in (5) korrek kan interpreteer en toepas om alternatiewe (10), (11) en (12) as vertaalekwivalente tot sy/haar beskikking te hê sonder dat dit vir die leksikograaf nodig was om elkeen afsonderlik aan te bied:

(10) die stuipe kry

(11) die aapstuipe kry

(12) die bobbejaanstuipe kry

Die relatiewe plasing van die hakies en die vorme wat daardeur in- of uitgesluit word, maak ook die ortografiese implikasies verbonde aan die alternatiewe vorme duidelik. Op dié manier is dit byvoorbeeld duidelik ten opsigte van (8) dat die komma na die tweede hô (slegs) nodig is indien 'n derde hô 
bygevoeg word. Met betrekking tot die los of vas skryf van woorde is dit duidelik dat die plasing van die vorme tussen hakies in (5) (aap/bobbejaan) téénaan die daaropvolgende vorm (stuipe) impliseer dat die saamgestelde vorm as een woord geskryf word, dus aapstuipe en bobbejaanstuipe teenoor die foutiewe aap stuipe en bobbejaan stuipe.

Ander inligtingstipes wat duidelik aan die gebruiker in die toeligting gestel word, is uitspraakleiding en lettergreepaanduiding (vgl. die bespreking oor uitspraakleiding onder 4.1), woordklas, meervoude, tempus, die aanwending van die tilde, die dubbel- en enkelkoppelteken, die kruisverwysingsmerker, betekenisindikators (aanvullende semantiese kommentaar), etikette en kollokators.

Die vernuwende manier waarop die "Key to entries" in NW saamgestel is, verteenwoordig baanbrekerswerk in standaard Afrikaanse vertalende woordeboeke. Die leksikograaf gee nie alleen verantwoording van sy/haar mikrostrukturele struktuurplan nie, maar doen dit ook op 'n maklik verstaanbare en geredelik toeganklike manier. So 'n gebruikersvriendelike aanbod staan 'n groter kans om die gebruiker werklik in sy/haar naslaanaktiwiteit van hulp te wees deur die mikrostruktuur toeganklik te maak. Verder kan die eenvoudige aanbod ook die gemiddelde gebruiker se ignorering van die woordeboek se voorwerk tot 'n mate begin teenwerk, wat weer indirek kan bydra tot 'n uitbreiding van die gebruiker se inligtingsontsluitingsvaardighede deur kennisname van die inligtingstipes wat in 'n woordeboekartikel vervat word.

Dit is wel noodsaaklik dat álle beginsels en middele wat in die woordeboek geld en aangewend word, duidelik en volledig in die toeligting verantwoord word. By gebrek hieraan ly die woordeboek se toeganklikheid skade.

\subsection{Die lys redaksionele afkortings}

Die lys redaksionele afkortings in NW is verteenwoordigend van die tradisionele aanbod van sodanige afkortings in Afrikaanse tweetalige woordeboeke (vgl. GW).

Enkele tegniese tekortkominge bestaan in hierdie deel van die voorwerk. Die afkorting $v$. staan volgens die lys vir verbum (werkwoord), maar die afkorting word in die mikrostruktuur ook as afkorting vir die setsel van in semantiese kommentaar aangewend, soos wat uit die onderstaande uittreksel blyk:

cra que-lure $n_{\text {., }}$ (netwerk $v$. fyn krakies/barsies in verf/vernis/glasuur) krakeluur.

Die aanwending van die afkorting verb. vir verbum (werkwoord) in plaas van $v$. kan die probleem uit die weg ruim.

Ten minste een Afrikaanse redaksionele afkorting wat in die mikrostruktuur voorkom, verskyn nie in die lys redaksionele afkortings nie, naamlik die 
afkorting iem. (vir iemand), soos uit die onderstaande uittreksel blyk:

(14) a'bun dant ly adv.: be - clear (to s.o.) that ... (vir iem.) glashelder/alte duidelik wees dat ... [...].

Uit die uittreksel in (14) hierbo val ook die gebruik van die Engelse redaksionele afkorting s.o. (vir someone) op. Hier faal die lys van redaksionele afkortings in NW daarin dat geen Engelse redaksionele afkortings in die lys opgeneem is nie. In die lig van die vroeëre vraag na die rede vir die redaksie se besluit om die "Key to entries" se byskrifte in Engels aan te bied, wil dit tog begin voorkom asof die algehele aanbod van die voorwerk in NW by 'n heroorweging baat sou vind. Die Engelse aanbod in die "Key to entries" staan in skerp kontras tot die totale afwesigheid van die verklaring van Engelse redaksionele afkortings in die lys redaksionele afkortings. Dit lyk asof noukeuriger kontrole oor die aanwending en opname van redaksionele afkortings nodig mag wees.

'n Oplossing in hierdie verband mag ' $n$ voorstel wees dat die lys redaksionele afkortings onderverdeel word in Afrikaanse teenoor Engelse redaksionele afkortings enersyds, en andersyds in redaksionele afkortings wat bloot ruimtebesparend optree (bv. bv., v.d.) teenoor gebruiks-, vaktaal- en styletikette (bv. akr., geol., sl.). Sodanige onderverdeling het die tweeledige voordeel dat die gebruiker in een oogopslag van die aard van die relevante inligtingstipes bewus gemaak word én dat dit die leksikograaf minder ruimte laat vir vergissing ten opsigte van duplisering of ander foute wat betref afkortings.

Soos vroeër opgemerk, is dit duidelik dat die redaksie van NW deeglik van die taalkundige inligtingsaspek van die woordeboek bewus is (vgl. ook weer Lombard 1994). Hierdie bewustheid word verder gemanifesteer in die aanbod van woordklas in taalkundig eenduidiger terme, soos adjektief, adverbium, nomen, prefiks, preposisie, suffiks en verbum. 'n Enkele potensieel verwarrende nalatigheid is dat beide die terme verbum en werkwoord apart in die lys verskyn, terwyl slegs verbum in die mikrostruktuur ter sprake is. Dié term word egter ook tussen hakies as werkwoord gekwalifiseer. Die taalkundig eenduidiger terme wat in die NW se lys redaksionele afkortings opgeneem is, is egter ook toeganklik vir die taalkundig ongeskoolde gebruiker deurdat die tradisionele woordklasaanduidings tussen hakies na die taalkundige terme volg. Vergelyk:
(a) adverbium (bywoord)
(b) prefiks (voorvoegsel)
(c) preposisie (voorsetsel)

Dit is duidelik dat die redaksie sowel die taalkundig geskoolde gebruiker as die taalkundige leek by hierdie inklusiewe aanbod van taalkundige inligting probeer akkommodeer. Dit verteenwoordig gewis 'n nuwe rigting in die Afrikaanse leksikografie - een wat prysenswaardig is. 


\subsection{Die agterwerk}

In die agterwerk van NW verskyn 'n glossarium van algemene afkortings. Binne Wiegand (1996) se teksbenadering is die glossarium as deel van die agterwerk opsioneel; die afkortings sou dus ook op hul alfabetiese plekke in die makrostruktuur opgeneem en bewerk kon word. Die buitemikrostrukturele leksikografiese hantering van dié inligtingstipe verhoog egter die toeganklikheid daartoe, aangesien individuele items makliker in die glossariumformaat gevind kan word omdat hulle nie van uitgebreide bewerkings voorsien hoef te word nie. In GW verskyn soortgelyke glossaria aan die einde van die Afrikaans-Engels-deel en aan die einde van die Engels-Afrikaans-deel onderskeidelik. Aangesien NW nie 'n tweerigting vertalende woordeboek is nie, word die Engelse volvorme van die aangebode afkortings gegee, gevolg deur die Afrikaanse volvorme en die korresponderende Afrikaanse afkortings, waar van toepassing. Uit die aard van die woordeboek is 'n omgekeerde aanbod nie ingesluit nie. Vergelyk (16) hieronder:

prop. proposition $\bullet$ aanbod aanb.

(b) Q, Q. question • vraag

In (16)(b) is die alternatiewe afkortingsmoontlikhede vir question ( $Q$ óf $Q$.) duidelik, terwyl die afwesigheid van 'n Afrikaanse afkorting in dié geval impliseer dat daar nie in Afrikaans 'n afkorting vir vraag is nie. Ook hierdie tipe volledige inligtingsaanbod word ongelukkig nie konsekwent deurgevoer nie. Vergelyk die uittreksels in (17), waar geen Afrikaanse ekwivalent (volvorm óf afkorting) hoegenaamd aangebied word nie:
(a) rec. recipe
(b) rec. record
(c) WP, w.p. weather permitting

Die rede vir die onvolledige bewerking hierbo is nie afleibaar nie. In gevalle waar daar nie 'n Afrikaanse afkorting bestaan nie, word die Afrikaanse volvorm wel normaalweg gegee, soos in (16)(b) en in (18) hieronder:

(18) (a) VTR video tape recorder $\bullet$ videobandopnemer

(b) w/o without $\bullet$ sonder

(c) $\quad \mathrm{XL}$ extra large $\bullet$ ekstra groot

'n Vernuwing in die glossarium afkortings in NW is die verskynsel van etikettering van sommige afkortings. In hierdie instansie is NW 'n goeie voorbeeld van hoe die inligting in die toeligting in die voorwerk van 'n woordeboek ook vir die agterwerk van die woordeboek kan geld. Verder word 'n mate van kontinuïteit in terme van inligtingsaanbod tussen die alfabetiese deel van die 
woordeboek en die agterwerk bewerkstellig. Hierdie verskynsel onderskryf Wiegand (1996: 135) se siening dat al die tekste binne die woordeboek op funksionele en strukturele vlak met mekaar verband hou. Vergelyk die geëtiketteerde afkortings in (19) hieronder:

(19) (a) Pvt. (Am. mil.) private • weerman wrn.

(b) RAM (rek.) random-access memory - lees-en-skryf-geheue LSG, RAM

(c) TGIF (infml.) thank God it's Friday • dank Vader dis Vrydag DVDV

Dit is wel jammer dat geen melding van die agterwerk in die "Key to entries" (of desnoods in die Voorwoord) gemaak word nie. Hierdeur ly tekstuele eenheid binne die makroteks skade, en die gebruiker word nie ingelig dat sodanige agterwerk (en dus die betrokke inligtingstipe) wel bestaan nie.

\section{Die alfabetiese gedeelte van die woordeboek}

In hierdie afdeling sal die mikrostrukturele element van uitspraakleiding en die mediostruktuur in terme van leksikografiese vernuwings in NW oorsigtelik aandag geniet.

\subsection{Uitspraakleiding}

Daar bestaan uiteenlopende standpunte oor die aanbod van uitspraakinligting in vertalende woordeboeke. Wells (1985: 45) benader die aanbod van uitspraakinligting vanuit ' $n$ pragmatiese perspektief: "There is little need for such [i.e. pronunciation - HLB] information in a dictionary of Spanish or Finnish, for example, since in all except the rarest cases the pronunciation of a word in those languages may be safely inferred from its spelling, given the knowledge of the relevant 'reading rules' which express the relationship between phoneme and grapheme, speech and writing." Uitspraakinligting is wel nodig indien 'n taal soos Engels, waar die verband tussen ortografie en uitspraak nie so duidelik is nie, deel van die woordeboek uitmaak, voer Wells aan. Svensén (1993: 69) is meer uitgesproke oor uitspraakleiding en betoog dat "it has to be given in dictionaries intended for passive use". Die aard van die verhouding tussen ortografie en uitspraak is nie vir Svensén 'n oorweging nie; dit gaan oor die funksie van die woordeboek. Svensén (1993: 70-73) is egter nie baie krities oor hoe uitspraakinligting aangebied word nie: dit kan volgens hom óf as deel van die lemma, óf apart van die lemma, óf as deel van én apart van die lemma aangebied word. Fonetiese transkripsie is dus nie 'n vereiste nie. Oor die opmerklike afwesigheid van fonetiese transkripsies in Afrikaanse vertalende woordeboeke handhaaf Sakurai en Kotzé (1997: 169) die standpunt dat die rede daarvoor voor die hand liggend is: "Dit word as onnodig beskou vir die woor- 
deboekgebruikers, almal Suid-Afrikaners wat elke dag ouditief aan Afrikaans blootgestel word." Dié argument kan egter nie sonder meer aanvaar word nie. Dit sou waarskynlik akkurater wees om te beweer dat die meeste gebruikers van Afrikaanse vertalende woordeboeke Suid-Afrikaners is, en dat hierdie (en nie-Suid-Afrikaanse) gebruikers in verskillende grade (indien enigsins) ouditief aan Afrikaans blootgestel word, en boonop nié noodwendig elke dag nie.

Gouws (1989: 265) lewer die felste kritiek wanneer hy beweer dat uitspraak ' $n$ inligtingstipe is wat nog nie met genoeg sorg en uitvoerigheid in Afrikaanse woordeboeke hanteer word nie: "Dit is veral in die vertalende woordeboeke dat uitspraakinligting uiters onbevredigend aangebied word. Sowel die GW (Groot Woordeboek/Major Dictionary - HLB) as die TW (Tweetalige Woordeboek/Bilingual Dictionary - HLB) bied slegs die hoofklem van lemmas aan." Uit ' $n$ taalkundige oogpunt bly 'n fonetiese transkripsie die suksesvolste manier van uitspraakleiding: "Dit skep ook die ideale terrein vir die toepassing van ander uitspraakinligtingstipes soos klemaanduiding en sillabeverdeling" (Gouws 1989: 268). Ongelukkig is 'n stelsel van fonetiese transkripsie ook in NW afwesig.

Hoewel klemaanduiding in NW steeds ten opsigte van die geskrewe vorm van die lemma verstrek word, en nie volgens die klanklike weergawe daarvan nie (vgl. Gouws 1989: 266), tree NW wel daarin vernuwend op dat klemaanduiding geskied deur die onderstreping van die sillabe waarop die hoofklem in 'n meersillabige lemma val. Vergelyk die voorbeelde in (20) hieronder:
(a)
ab·sen tee $n .:[\ldots]$

Hierdie wyse van klemaanduiding, hoewel nog nie die ideale vorm nie, is verkieslik bo die gebruik van klemstrepies, soos wat in GW aangewend word, aangesien die plasing daarvan verwarring by die gebruiker kan veroorsaak in die lig van die feit dat verskillende woordeboeke verskillende benaderings volg: sommiges plaas die strepie voor die sillabe wat die hoofklem dra; ander plaas die strepie daarná. Vergelyk klemaanduiding by die lemma adult in GW, wat effektief geen leiding ten opsigte van die korrekte uitspraak van dié item bied tensy die gebruiker seker is van die betrokke woordeboek se stelsel van klemaanduiding nie:

\section{(21) ad'ult}

Deur die sillabe waarop die hoofklem val te onderstreep, word enige moontlike verwarring uitgeskakel. Hierdie praktyk getuig weer eens van die redaksie se sterk gebruikersvriendelike aanslag in NW.

Hoewel die aanduiding van lettergrepe (teenoor sillabes) nie eintlik tuishoort onder uitspraakleiding in 'n woordeboek nie, kan dit hier genoem word 
dat hierdie inligtingstipe glad nie in GW voorkom nie, terwyl ten opsigte van die NW van 'n volledige en welkome vernuwing op hierdie gebied sprake is. Lettergreepgrense word naamlik deur kolletjies binne die lemma aangedui (vgl. o.a. die voorbeelde in (20)).

Ongelukkig is dit nie die ideale taalkundige toestand dat lettergreepverdeling en hoofklemaanduiding ten opsigte van een en dieselfde weergawe van die lemma aangedui word nie. Die gebruiker kry in die afwesigheid van 'n fonetiese transkripsie ook steeds onvoldoende uitspraakleiding wanneer hy/sy voor 'n lemma soos vol-au-vent te staan kom. Vanuit 'n meer pragmatiese oogpunt moet die redaksie van NW egter gelukgewens word met die vars en gebruikersvriendelike aanbod van tradisionele uitspraakinligting in Afrikaanse vertalende woordeboeke en die byvoeging van inligtingstipes wat tot dusver in geen standaard Afrikaanse vertalende woordeboek voorkom nie.

Indien NW egter as meer verantwoordbare houer van taalkundige inligting wil geld (soos wat die reeds aangeduide vernuwings suggereer), is die insluit van 'n stelsel van fonetiese transkripsie noodsaaklik. Dit is tog jammer dat die redaksie van NW nie ook hierdie vernuwende stap kon neem nie. Volgens Louw (1997: 85) sou fonetiese transkripsies nie die toeganklikheid of gebruikersvriendelikheid van die woordeboek aantas nie: "Die aanpassing wat die aanleer of gebruik van die fonetiese alfabet van die deursneegebruiker sal verg, is nie veel groter as wat die aanleer en gebruik van byvoorbeeld RD (Reader's Digest Afrikaans-Engelse Woordeboek/English-Afrikaans Dictionary HLB) se sleutels sal verg nie. Verder word die bate van ondubbelsinnigheid toegevoeg ... Transkripsies volgens 'n fonetiese alfabet [is] die beste opsie, mits 'n deeglike, toeganklike gids gegee word verkieslik in die voorwerk." Boonop sou oortuigend geargumenteer kon word dat die teikengebruiker van NW ook (ten minste by geleentheid) Engelse verklarende woordeboeke raadpleeg. In die lig van die feit dat Engelse verklarende woordeboeke byna sonder uitsondering fonetiese transkripsies in uitspraakleiding aanwend, behoort sodanige gebruiker nie verlore te voel indien fonetiese transkripsies dan in 'n Afrikaanse vertalende woordeboek sou verskyn nie.

Omdat NW 'n eenrigting vertalende woordeboek is, sal by die insluit van fonetiese transkripsie oor die adresseringsprosedure daarvan besin moet word. Gegee dat die waarskynlikste gebruiker van NW Afrikaanssprekend is, soos afgelei kan word uit die huidige Suid-Afrikaanse sosiolinguistiese konteks tesame met die algemene gerigtheid van die woordeboek, sou 'n stelsel van lemmatiese adressering voorgestel word.

\subsection{Mediostruktuur}

Volgens Gouws en Prinsloo (1998: 18) is een van die belangrikste eienskappe van 'n goeie woordeboek sy toeganklikheid. Toeganklikheid lei tot eenduidige inligtingsontsluiting op beide die makro- en mikrostrukturele vlakke. Toeganklikheid in NW word verhoog deur die implementering van 'n stelsel van eks- 
plisiete kruisverwysing. Volgens Svensén (1993: 194) gebruik baie woordeboeke eksplisiete kruisverwysings op 'n lukraak wyse deur geen of gebrekkige leiding vir verwysingsmerkers te bied. In NW word die kruisverwysingsmerker $\rightarrow$ egter in die toeligting ("Key to entries") in die voorwerk opgeneem en verduidelik aan die hand van die volgende voorbeeldartikel:

ec.o.dis.ạs.ter $n$. lecocatastrophe.

Naas dié voorbeeldartikel verskyn die volgende byskrif:

(23) Cross-reference: Look for the information at the word that comes after the arrow.

Die gebruiker wat die toeligting raadpleeg, sal dadelik die betekenis van die pyltjie in 'n woordeboekartikel snap en die nodige inligting maklik bekom deur die kruisverwysingsverband op te neem. Vergelyk die volgende NW-artikels waarin eksplisiete kruisverwysing voorkom:

(24) (a) bald a.: - eagle leagle.

(b) eag.le $n .:$ bald - Amerikaanse adelaar.

(25) (a) so pra-no [...] - recorder $(A m$.) descant recorder.

(b) des'cant, dis.cant $n$. $\mathcal{E}$ a.: - recorder sopraanblokfluit.

Suksesvolle verwysing is tussen die verwysingsinskrywing in (24) (a) en (25)(a) en die verwysingsadres in (24)(b) en (25)(b) onderskeidelik bewerkstellig. Dit is 'n tegniek wat konsekwent in NW toegepas word, en wat 'n merkbare verbetering op GW se mediostruktuur verteenwoordig.

Daar kom egter een verwysingsmerker in die mikrostruktuur van NW voor wat nie in die toeligting verduidelik word nie, naamlik die gelykheidsteken (=) (vgl. (1), (2) en (3) onder 3.1). In hierdie gevalle bestaan die verwysingsadres nie, aangesien die items wat op die gelykheidsteken volg, nie in die makro- of mikrostruktuur opgeneem is nie. Hoewel die gebruik van die gelykheidsteken 'n geval van wisselvormlemmas suggereer in terme van Gouws (1989: 76) en Svensén (1993: 195), negeer die afwesigheid van die verwysingsadres dié aanname. Hier faal NW daarin dat daar uiteindelik geen Afrikaanse ekwivalent vir 'n Engelse lemma aangebied word nie, maar dat die gebruiker bloot na 'n niebestaande lemma verwys word. Dit wil selfs voorkom asof die Engelse wisselvorm wat op die gelykheidsteken volg as 'n tipe ekwivalent aangebied word. Die leksikograaf moet sistematies te werk gaan en kan nie van die gebruiker verwag om van sy/haar intuïsie gebruik te maak indien die aanwending van spesiale simbole in die mikrostruktuur nêrens in die toeligting verklaar word nie.

Aangesien NW as 'n aanvullende woordeboek ten opsigte van veral GW geld, sou geargumenteer kon word dat kruisverwysing deur die gelykheids- 
teken 'n spesiale soort eksterne verwysingsadres (ekstrawoordeboek-verwysingsadres) aandui, naamlik 'n lemma wat nie in NW nie, maar in GW verskyn. Wiegand (1996: 141) maak in sy uiteensetting van mediostrukture binne die teksbenadering voorsiening vir intertekstuele mediostrukture, waaronder mediostrukture wat 'n netwerk tussen verskillende woordeboeke bewerkstellig, ressorteer. Binne die relatief spesiale funksie van NW sou dus tereg van sodanige intertekstuele mediostruktuur sprake kon wees, maar die feit bly staan dat dié gebrekkig verklaarde reëling die gebruiker in die duister kan laat en sodoende die toeganklikheid van die woordeboek skade berokken.

Afgesien van die bogenoemde tekortkominge lewer NW welkome vernuwings ten opsigte van die mediostruktuur in Afrikaanse vertalende woordeboeke. Die redaksie sou daarby kon baat om noukeuriger kontrole uit te oefen oor die presiese inhoud van die toeligting in die voorwerk en hoe dit vergelyk met wat in die mikrostruktuur aangetref word. Uiteraard is die volledige verklaring van álle tipografiese verskynsels in die mikrostruktuur die ideaal.

\section{Perspektief}

Hoewel NW ongetwyfeld verdere leksikografiese vernuwings op mikrostrukturele vlak bevat, is in hierdie artikel hoofsaaklik gefokus op aspekte wat miskien nie altyd die aandag ontvang nie, en vanweë hulle relatiewe agtergesteldheid gevolglik die oorhoofse kwaliteit van die woordeboek deur beperkte toeganklikheid nadelig kan beïnvloed. Die redaksie van NW het bewys dat buitemikrostrukturele leksikografiese vernuwings 'n baie belangrike rol in die gebruikersvriendelik maak van 'n woordboek kan en behoort te speel.

\section{Verwysings}

\section{Woordeboeke}

Bosman, D.B., I.W. van der Merwe en L.W. Hiemstra. 1984. Tweetalige woordeboek/Bilingual Dictionary. Kaapstad: Tafelberg.

Eksteen L.C. 199714. Groot Woordeboek/Major Dictionary. Kaapstad: Pharos.

Grobbelaar, P. (Red.). 1987. Reader's Digest Afrikaans-Engelse Woordeboek/English-Afrikaans Dictionary. Kaapstad: The Reader's Digest Association.

Joubert, P.A. 1997. Tweetalige Frasewoordeboek/Bilingual Phrase Dictionary. Kaapstad: Pharos.

\section{Ander bronne}

Gouws, R.H. 1989. Leksikografie. Pretoria en Kaapstad: Academica.

Gouws, Rufus H. 1996. Bilingual Dictionaries and Communicative Equivalence for a Multilingual Society. Lexikos 6: 14-31. 
Gouws, R.H. 1999. Die maatskaplike gerigtheid van die metaleksikografie in 'n meertalige samelewing. Intreerede. Stellenbosch: Universiteit van Stellenbosch.

Gouws, R.H. en D.J. Prinsloo. 1998. Cross-Referencing as a Lexicographic Device. Lexikos 8: 17-36.

Hausmann, F.J. 1989. Die gesellschaftlichen Aufgaben der Lexikographie in Geschichte und Gegenwart. Hausmann, F.J. et al. (Reds.). 1989-1991: 1-19.

Hausmann, F.J. et al. (Reds.). 1989. Wörterbücher. Ein internationales Handbuch zur Lexikographie / Dictionaries. An International Encyclopedia of Lexicography / Dictionnaires. Encyclopédie internationale de lexicographie. Berlyn/New York: Walter de Gruyter.

Kromann, Hans, Theis Riiber en Poul Rosbach. 1991. Principles of Bilingual Lexicography. Hausmann, F.J. et al. (Reds.). 1989-1991: 2711-2728.

Lombard, F.J. 1994. Lexicographer, Linguist and Language User: An Uneasy Triangle? Lexikos 4: 204-214.

Louw, Phillipus Adriaan. 1997. Kriteria vir 'n standaard vertalende woordeboek. Ongepubliseerde M.A.-skripsie. Stellenbosch: Universiteit van Stellenbosch.

Louw, Phillip Adriaan en Rufus Hjalmar Gouws. 1996. Lemmatiese en nielemmatiese adressering in Afrikaanse vertalende woordeboeke. Suid-Afrikaanse Tydskrif vir Taalkunde 14(3): 92-100.

Sakurai, Takashi en Ernst F. Kotzé. 1997. 'n Kontrastiewe beskouing van tweetalige woordeboeke in Suid-Afrika en Japan. Lexikos 7: 165-178.

Svensén, Bo. 1993. Practical Lexicography. Principles and Methods of Dictionary-Making. Oxford: Oxford University Press.

Van der Merwe-Fouché, Michele. 1999. Gebruikersperspektief in die leksikografie. Ongepubliseerde D.Litt.-proefskrif. Stellenbosch: Universiteit van Stellenbosch.

Wells, J.C. 1985. English Pronunciation and its Dictionary Representation. Ilson, Robert (Red.). 1985. Dictionaries, Lexicography and Language Learning. Oxford: Pergamon.

Wiegand, Herbert Ernst. 1996. A Theory of Lexicographic Texts: An Overview. Suid-Afrikaanse Tydskrif vir Taalkunde 14(4): 134-149. 